\title{
Transforming Growth Factor- $\beta$, Interleukin-10, and Serological Markers in EBV-associated Gastric Carcinoma
}

\author{
DARIUSZ PACHNIA ${ }^{1}$, BARTŁOMIEJ DROP ${ }^{2}$, ANNA DWORZAŃSKA ${ }^{3}$, \\ EWA KLISZCZEWSKA ${ }^{3}$ and MAŁGORZATA POLZ-DACEWICZ ${ }^{3}$ \\ ${ }^{1}$ AMG Medical Center, Hospital in Ryki, Ryki, Poland; \\ ${ }^{2}$ Chair and Department of Public Health, Medical University of Lublin, Lublin, Poland; \\ ${ }^{3}$ Department of Virology, Medical University of Lublin, Lublin, Poland
}

\begin{abstract}
Background/Aim: The association between EpsteinBarr virus (EBV) and gastric cancer $(G C)$ has been reported by many researchers. Immunosuppressive cytokines, such as interleukin-10 (IL-10) and transforming growth factor $\beta$ (TGF $\beta$ ), play an important role in the tumor process. The aim of the present study was to detect antibodies against EBV and explore the levels of TGF $\beta$ and IL-10 in Polish GC patients. Patients and Methods: Fifty patients with GC and 50 hospitalized individuals without GC (control group) were enrolled in the study. Frozen tumor tissue fragments were tested using nested PCR assay for EBV DNA detection. ELISA test was used to detect the presence of anti-VCA IgG, anti-EBNA IgG, anti-EA IgG, TGF $\beta$ and Il-10 in sera from all individuals. Results: EBVCA was detected in $88.0 \%$, EBNA in $90.0 \%$, and EA in $72.0 \%$ of patients. Levels of TGF $\beta$ and IL-10 were significantly higher in patients with high levels of anti-EA antibodies (25.4 $\mathrm{ng} / \mathrm{ml} ; 7.8 \mathrm{pg} / \mathrm{ml}$ ) compared to patients with low levels of antiEA antibodies $(12.61 \mathrm{ng} / \mathrm{ml} ; 4.29 \mathrm{pg} / \mathrm{ml})$. Conclusion: The significantly higher level of EA in patients' sera indicates $E B V$ reactivation. TGF $\beta$ level was significantly higher in GC than in the control group, especially in EA-positive patients, indicating its possible role in gastric carcinogenesis.
\end{abstract}

Gastric cancer (GC) is the fifth most commonly diagnosed cancer and the third leading cause of cancer-related mortality worldwide (1). According to Cancer Atlas Research Network, GC is divided into 4 molecular types: GC positive for Epstein-Barr virus (EBV), GC with

This article is freely accessible online.

Correspondence to: Ewa Kliszczewska, Department of Virology, Medical University of Lublin, Racławickie 1 Street, 20-059 Lublin, Poland. Tel: +48 814486171, Fax: +48 814486170(71), e-mail: ewakliszczewska@gmail.com

Key Words: EBV antibodies, EBVaGC, TGF $\beta$, IL-10, LMP-1. microsatelite instability, genomically stable GC and GC with chromosomal instability (2).

Every year, more than 950,000 cases of gastric adenocarcinoma are diagnosed in the world and it is estimated that about $10 \%$ of these cases are associated with $\operatorname{EBV}(3,4)$. Each year worldwide it is estimated that there are about 84,000 cases of EBV-associated gastric carcinoma (5). EBV-positive gastric cancer cases constitute the largest group of EBVassociated cancers (4). In Poland, EBV-positive GC was $12.5 \%$, in 2012 (2). Though, there are very few publications on the serological status of GC patients, in the available world literature. In a meta-analysis by Chenan et al. (6), the authors found only 4 publications comparing the presence of anti-EBV antibodies between patients with GC and healthy individuals. There are specific serological markers of EBV infection that are useful indicators of exposure to infection and reactivation. For example, antibodies against Epstein-Barr virus capsid antigen (EBVCA), that is expressed in latent infection, anti-Epstein-Barr virus nuclear antigen (EBNA) that is primarily epidemiological, and anti-early antigen (EA), which might indicate the reactivation of latent infection $(6,7)$. In addition, many studies indicate that transforming growth factor- $\beta$ (TGF $\beta$ ) induces EBV reactivation in certain types of cancer $(8,9)$.

Therefore, the aim of the present study was to evaluate the levels of antibodies against EBV antigens: anti-EBVCA IgG, anti-EBNA IgG and anti-EA IgG, in order to determine the possible reactivation of the virus. Furthermore, levels of IL-10 and TGF- $\beta$ in sera of GC patients compared to the control group were estimated. Finally, we tested the incidence of latent membrane protein (LMP-1), a well-known oncoprotein that takes part in neoplastic transformation of EBV-infected B lymphocytes, and the 30 bp deletion variant del-LMP-1 (10).

\section{Materials and Methods}

Patients. The present study consisted of a group of 50 patients with diagnosed GC that were hospitalized at the Surgery Ward of Private Hospital in Nałęczów and AMG Hospital Center in Ryki, Poland. All patients were Helicobacter pylori-negative (based on the medical 
history of the patients). The results were compared to the control group, consisted of 50 individuals hospitalized at the same Ward due to diseases other than GC. There were no statistically significant differences between the patients and the control group (age, sex, tobacco and alcohol consumption). The socio-demographic and clinicopathological characteristics of the study group are shown in Table I. The research material consisted of sera and fresh frozen tumor tissue fragments. This research was approved by the Ethics Committee and is in accordance with the GCP regulations (no. KE0254/133/2013/Medical University of Lublin, Poland).

Molecular methods. DNA extraction from fresh frozen tumour tissue, detection of EBV DNA, amplification of EBNA-2 gene (the nested PCR) and serological tests for antibody level detection were performed as previously described (11). PCR screening for the EBV LMP-1 subtype based on exon 3, defined as wild-type (wt-LMP-1) or del-LMP-1, was analyzed as previously described (12).

Statistical analysis. Descriptive statistics were used to characterize patient baseline characteristics. The Mann-Whitney $U$-test and KruskalWallis test were used to compare the antibody and cytokine levels. Pearson's Chi-square test was used to investigate the relationship of LMP-1, clinical and demographical parameters between patients and control group. Statistical significance was defined as $p<0.05$.

\section{Results}

Men aged over 60 years and rural residents were predominant. GC was most frequently localized to the pylorus region (58.0\%), then to the body region (24.0\%), and the cardiac region of the stomach (18.0\%). Anti-EBVCA IgG were detected in $88.0 \%$ of GC patients and in $86.0 \%$ of control individuals, while antiEBNA IgG respectively in $90.0 \%$ and $84.0 \%$. Antibodies against early antigen (EA) were more frequent in patients $(72.0 \%)$ than in the control group (8.0\%) $(p<0.001)$. Levels of the studied antibodies and cytokines TGF $\beta$ and IL-10, were higher (24.4 $\mathrm{ng} / \mathrm{ml} ; 7.2 \mathrm{pg} / \mathrm{ml}$, respectively) in patients with EBV-associated GC (EBVaGC) than in control patients $(10.1 \mathrm{ng} / \mathrm{ml} ; 3.5 \mathrm{pg} / \mathrm{ml}$, respectively) $(p<0.001)$ (Table II). An association was detected between serum levels of TGF $\beta$, Il-10 and the level of the studied antibodies $(p<0.001)$. The patients infected with wild type LMP1 had a higher concentration of TGF $\beta(24.8 \mathrm{ng} / \mathrm{ml} v s .18 .1 \mathrm{ng} / \mathrm{ml}$ in del-LMP-1; $p<0.01$ ) (Table III).

\section{Discussion}

The number of publications on various aspects of GC is steadily increasing $(13,14)$. EBVaGC is more common in younger patients, between 50 and 68 years of age, while EBV-negative $\mathrm{GC}$ is more frequent among patients aged 56-72. Several risk factors for developing EBVaGC have been identified, i.e. tobacco smoking $(15,16,17)$. In our own study $64.0 \%$ were men over the age of 60 , most of them tobacco smokers (74\%).

Epidemiological analyses of EBV infection in GC (also in other cancers) are based on the results of laboratory tests detecting the presence of the virus in tumor tissue, i.e.
Table I. Socio-demographic and clinicopathological characteristics of patients and healthy individuals (control group).

\begin{tabular}{|c|c|c|c|c|c|}
\hline \multirow[t]{2}{*}{ Parameters } & \multicolumn{2}{|c|}{$\begin{array}{c}\text { Patients } \\
\mathrm{N}=50\end{array}$} & \multicolumn{2}{|c|}{$\begin{array}{l}\text { Control group } \\
\qquad \mathrm{N}=50\end{array}$} & \multirow[t]{2}{*}{$p$-Value } \\
\hline & $\mathrm{N}$ & $\%$ & $\mathrm{~N}$ & $\%$ & \\
\hline \multicolumn{6}{|l|}{ Gender } \\
\hline M & 31 & 64.0 & 33 & 66.0 & \multirow[t]{2}{*}{$>0.05$} \\
\hline $\mathrm{F}$ & 18 & 36.0 & 17 & 34.0 & \\
\hline \multicolumn{6}{|l|}{ Age } \\
\hline $40-59$ & 15 & 30.0 & 16 & 32.0 & \multirow[t]{2}{*}{$>0.05$} \\
\hline$>60$ & 35 & 70.0 & 34 & 68.0 & \\
\hline \multicolumn{6}{|c|}{ Place of residence } \\
\hline Urban & 10 & 20.0 & 10 & 20.0 & \multirow[t]{2}{*}{$>0.05$} \\
\hline Rural & 40 & 80.0 & 40 & 80.0 & \\
\hline \multicolumn{6}{|c|}{ Tobacco smoking } \\
\hline Yes & 37 & 74.0 & 35 & 70.0 & \multirow[t]{2}{*}{$>0.05$} \\
\hline No & 13 & 26.0 & 15 & 30.0 & \\
\hline \multicolumn{6}{|l|}{ Alcohol abuse } \\
\hline Yes & 35 & 70.0 & 33 & 66.0 & \multirow[t]{2}{*}{$>0.05$} \\
\hline No & 15 & 30.0 & 17 & 34.0 & \\
\hline \multicolumn{6}{|l|}{ G } \\
\hline G1 & 8 & 16.0 & - & & \\
\hline $\mathrm{G} 2$ & 32 & 64.0 & - & & \\
\hline G3 & 10 & 20.0 & - & & \\
\hline \multicolumn{6}{|l|}{$\mathrm{T}$} \\
\hline $\mathrm{T} 1$ & 6 & 12.0 & - & & \\
\hline $\mathrm{T} 2$ & 38 & 76.0 & - & & \\
\hline $\mathrm{T} 3$ & 6 & 12,0 & - & & \\
\hline $\mathrm{T} 4$ & 0 & 0 & - & & \\
\hline \multicolumn{6}{|l|}{$\mathrm{N}$} \\
\hline No & 20 & 40.0 & - & & \\
\hline $\mathrm{N} 1$ & 13 & 26.0 & - & & \\
\hline N2 & 7 & 14.0 & - & & \\
\hline N3 & 10 & 20.0 & - & & \\
\hline \multicolumn{6}{|l|}{ M } \\
\hline M0 & 50 & 100.0 & - & & \\
\hline M1 & - & - & & & \\
\hline \multicolumn{6}{|l|}{ Location } \\
\hline Pylorus & 29 & 58.0 & - & & \\
\hline Body & 12 & 24.0 & - & & \\
\hline Cardia & 9 & 18.0 & - & & \\
\hline \multicolumn{6}{|l|}{ EBV type } \\
\hline Wild & 39 & 78.0 & - & & \\
\hline del-LMP-1 & 11 & 22.0 & - & & \\
\hline \multicolumn{6}{|c|}{ Antibodies positive } \\
\hline EBVCAIgG & 44 & 88.0 & 43 & 86.0 & $>0.05$ \\
\hline EBNAIgG & 45 & 90.0 & 42 & 84.0 & $>0.05$ \\
\hline EA IgG & 36 & 72.0 & 4 & 8.0 & $0.001 *$ \\
\hline
\end{tabular}

*Statistically significant. M, Male; F, female; EBV, Epstein-Barr virus; delLMP-1, LMP1 30bp-deletion variants; EBVCA, Epstein-Barr virus capsid antigen; EBNA, Epstein-Barr virus nuclear antigen; EA, early antigen.

principally in situ hybridization (ISH) or PCR and serological tests to assess the presence and/or titer of specific antibodies in patients' sera (18). In the present study, PCR was used to detect the presence of EBV DNA. 
Table II. Serum level of anti-EBVCA, anti-EBNA, TGF $\beta$ and IL-10 in patients and healthy individuals (control group).

\begin{tabular}{|c|c|c|c|c|c|}
\hline anti-EBV & Means $\pm S D$ & $p$-Value & Cytokine & Means \pm SD & $p$-Value \\
\hline EBVCA & & & TGF $\beta$ & & \\
\hline Control & $33,04 \pm 2.8$ & & Controls & $10.1 \pm 3.1$ & $0.001 *$ \\
\hline GC Patients & $66,7 \pm 6.3$ & $0.000045^{*}$ & Patients & $24.4 \pm 6.8$ & \\
\hline EBNA & & & IL-10 & & \\
\hline Control & $45,5 \pm 5.7$ & & Controls & $3.5 \pm 1.4$ & $0.001 *$ \\
\hline GC Patients & $69,4 \pm 2.1$ & $0,00001 *$ & Patients & $7.2 \pm 3.1$ & \\
\hline
\end{tabular}

*S tatistically significant. anti-EBVCA, Anti-Epstein-Barr virus capsid antigen; anti-EBNA, anti-Epstein-Barr virus nuclear antigen; TGF $\beta$, transforming growth factor $\beta$; IL-10, interleukin- 10 .

EBV is very widespread in the world, so approximately $95 \%$ of the population is detected with EBV-related antibodies. In a meta-analysis by Chenan et al. (6), EBNA IgG and EBVCA IgG were more frequently detected than the other antibodies, in both patients and control group. In our study, the prevalence of anti-EVBCA and anti-EBNA was similar in the GC and the control group, though titers of these antibodies differed between the groups, as both were significantly higher in EBVaGC patients. Anti-EA antibodies were found in $72 \%$ of patients with GC, of which $50 \%$ in high titer, while they were detected only in $17 \%$ of the control group, at very low titers. High anti-EA titers at the same time with high anti-EBVCA and antiEBNA levels might indicate the reactivation of $\mathrm{EBV}$ infection in patients with GC.

A scientific research in Japan has shown statistically higher levels of EBVCA among GC than in control (19). On the other hand, Shinkura et al. (7) and Kayamba et al. (20) showed higher anti-EA antibody titers in patients with EBVaGC. This fact would suggest a re-activation of infection in the early stages of neoplastic transformation $(21,22)$.

An important feature of $\mathrm{EBV}$, as well as of the entire Herpesviridae family, is the ability to enter into latency (23, $24)$, in which only some genes are expressed $(25,26)$.

EBVaGC is considered as a latency type I or II EBV infection, (18), in which i.e. EBNA-1, EBNA-2, LMP-1 and LMP-2 are expressed. EBNA-1 is present in all types of latency, and as the only EBNA type protein is also produced during activation into the lytic cycle. EBNA-2 is the major transcription factor regulating the expression of viral genes. It activates, among others, the LMP-1 and LMP-2 promoters and also transactivates many cellular genes that play a key role in cell proliferation and immortalization after infection (18).

Wang et al. (27) state that EBVaGC exhibits type I latency and, therefore, LMP-1 is not expressed. The authors show that the expression of LMP-1 occurs much more frequently in nasopharyngeal cancer (NPC). Some studies indicate low,
Table III. Correlation between serum levels of $T G F \beta, I L-10, E B N A$, EBVCA, anti-EA and LMP-1 type.

\begin{tabular}{lcccc}
\hline Parameters & TGF $\beta$ & IL-10 & EBNA & EBVCA \\
\hline EA + & $25.45 \pm 6.79$ & $7.81 \pm 3.7$ & 78.4 & 67.7 \\
EA - & $12.61 \pm 6.23$ & $4.29 \pm 1.7$ & 47.9 & 38.0 \\
$p$-Value & $0.0003^{*}$ & $0.016^{*}$ & $0.0001^{*}$ & $0.0001^{*}$ \\
wt-LMP-1 & 24.8 & 7.8 & 64.8 & 68.5 \\
del-LMP-1 & 18.1 & 7.4 & 69.4 & 76.6 \\
$p$-Value & $0.01^{*}$ & $>0.05$ & $>0.05$ & $>0.05$ \\
\hline
\end{tabular}

* Statistically significant. Del-LMP-1, LMP1 30bp-deletion variants; TGF $\beta$, transforming growth factor $\beta$; IL-10, interleukin-10; EBNA, Epstein-Barr virus nuclear antigen; EBVCA, Epstein-Barr virus capsid antigen; anti-EA, anti-early antigen; LMP-1 type, latent membrane protein 1; wt-LMP-1, wild-type latent membrane protein 1.

while others show high LMP-1 expression in the EBVaGC (18). The type of virus with a deletion is more common in NPC (28). However, in a study in Japanese GC patients, the incidence of del-LMP-1 was similar in both the study and control group (29).

The results obtained from this study indicate that the LMP1 protein was detected in all cases, which would indicate the presence of type II latency. The wild-type LMP-1 was detected in a predominant proportion $(78 \%)$, while a del-LMP1 was found in $22 \%$. Tsao et al. (30) suggest that LMP-1 might play a different role in early and late stages of carcinogenesis. High expression of LMP-1 can lead to deregulation of the cytotoxic effect of tumor cells and increased rates of mutation and methylation EBVaGC, though authors state the need for further research on this field.

We were further demonstrated that all patients with EBV del-LMP-1 had a high serum anti-EA antibody titer, while $30 \%$ of GC patients with the wild type had high anti-EA titer and $60 \%$ low. In addition, there were observed high TGF $\beta$ 
levels $(24.8 \mathrm{ng} / \mathrm{ml})$ in patients with wild-type LMP-1, which stimulated the reactivation of latent infection. It can, therefore, be assumed that the wild type plays a greater role in the pathogenesis of GC. However, the limitation of our study was that the sample size was quite small to make inferences about the Polish population means.

Reactivation of the virus and entry into the lytic cycle might be induced by various causes, including decrease in host resistance, various chemicals (31), and TGF $\beta$ (32).

Immunosuppressive cytokines, such as IL-10 and TGF $\beta$, play an important role in the tumor process (33-39). In the present study, IL-10 was significantly higher in patients with GC $(7.2 \mathrm{pg} / \mathrm{ml})$, and in patients with high titers of anti-EA $(7.8 \mathrm{pg} / \mathrm{ml})$. In patients with high levels of IL-10 a high titer of anti-EBNA was antibody also observed. Viral IL-10 (vil10), which exhibits high homology with human IL-10, is secreted late in the lytic phase and also at the onset of $B$ lymphocytes infection. (40). IL-10 levels, as shown by other studies, are statistically higher in the serum of GC patients than in the control group and therefore might predict GC and, particularly, could be used for the assessment of disease progression $(41,42)$. Our results showed higher serum levels of TGF $\beta$ in patients with EBVaGC (24.4 ng/ml) compared to the control group (10 ng/ml). In studies by Shukla et al. (32) carried out on a group of 95 patients with EBVaGC, TGF $\beta$ mRNA expression was detected in $89.5 \%$ of cases, indicating the role of TGF $\beta$ in the development of GC. In addition, they found that TGF $\beta$ expression was closely related to the lytic phase of infection in patients without $H$. pylori. These researchers suggest that TGF $\beta$ plays a role in the reactivation of EBV. In this study, TGF $\beta$ concentration correlated with the high anti-EA antibody titer $(25.44 \mathrm{ng} / \mathrm{ml}$ vs. $7.8 \mathrm{ng} / \mathrm{ml}$, respectively). On the other hand, there was no such relationship between EBVCA and EBNA.

Genetic and epigenetic changes also take part in the process of tumor transformation of gastric epithelial cells. Up to now, 9 high-expression viral genes in EBVaGC have been described (43). It has also been found that in EBVaGC cases, mutations can occur in approximately 205 cell genes, including TGF $\beta$ receptor TGFBR1, which is a serine-threonine kinase protein. Induced EBV infection with TGFBR1 mutation may be of importance for EBVaGC pathogenesis (43). In vitro studies of EBVaGC have shown that epigenetic changes also affect the expression of many genes. A correlation between EBVaGC and $\mathrm{CpG}$ methylation was detected suggesting that hypermethylation of entire groups of genes promotes gastric epithelial cell transformation (43).

\section{Conclusion}

Our results show that antibodies against EBV are frequent (EBVCA - 88.0\%, EBNA - 90.0\%, EA - 72.0\%) and the wild-type LMP-1 is predominant (78.0\%) in Polish patients with GC. The significantly higher level of EA in the patients points to EBV reactivation. TGF $\beta$ level was significantly higher in GC than in control group, especially in EA-positive patients, suggesting its role in gastric carcinogenesis. However, further studies are necessary to understand the complex mechanisms of tumor transformation that gastric epithelial cells undergo.

\section{Ethics Approval and Consent to Participate}

This research was approved by the Ethics Committee and is in accordance with the GCP regulations (no. KE-0254/133/2013/ Medical University of Lublin, Poland).

All participants provided written informed consent to participate in this study according to forms required by the Local Ethics Committee.

\section{Conflicts of Interest}

The Authors declare that they have no competing interests.

\section{Funding}

This study was supported by a Research Grant from the Medical University of Lublin, Lublin, Poland (DS 233).

\section{References}

1 Torre LA, Bray F, Siegel RL, Ferlay J, Lortet-Tieulent J and Jemal A: Global cancer statistics, 2012. CA Cancer J Clin 65(2): 87-108, 2015.

2 Cancer Genome Atlas Research Network: Comprehensive molecular characterization of gastric adenocarcinoma. Nature 513(7517): 202-209, 2014.

3 Liu S, Zhao Z, Han L, Liu S and Luo B: Epstein-barr virus infection in gastric remnant carcinoma and recurrent gastric carcinoma in qingdao of northern China. PloS One 11(2): e0148342, 2016.

4 Jacome AA, de Lima EM, Kazzi AI, Chaves GF, de Mendonca DC, Maciel MM and Dos Santos JS: Epstein-Barr virus-positive gastric cancer: a distinct molecular subtype of the disease? Rev Soc Bras Med Trop 49(2): 150-157, 2016.

5 Cohen JI, Mocarski ES, Raab-Traub N, Corey L and Nabel GJ: The need and challenges for development of an Epstein-Barr virus vaccine. Vaccine 31(02): B194-B196, 2013.

6 Chen XZ, Chen H, Castro FA, Hu JK and Brenner H: EpsteinBarr virus infection and gastric cancer: a systematic review. Medicine 94(20): e792, 2015.

7 Shinkura R, Yamamoto N, Koriyama C, Shinmura Y, Eizuru Y and Tokunaga M: Epstein-Barr virus specific antibodies in Epstein-Barr virus -positive and -negative gastric carcinoma cases in Japan. J Med Virol 60(4): 411-416, 2000.

8 Diaz Orea MA, Muñoz Perez V, Gómez Conde E, Castellanos Sánchez VO, Gonzalez Lopez R, Flores Alonso JC, Cárdenas ME, Galicia AL and Mendoza A: Expression of cytokines interleukin-2, interleukin-4, interleukin-10 and transforming growth factor $\beta$ in gastric adenocarcinoma biopsies obtained from Mexican patients. Asian Pac J Cancer Prev 18(2): 577-582, 2017. 
9 Ishimoto T, Miyake K, Nandi T, Yashiro M, Onishi N, Huang KK, Lin SJ, Kalpana R, Tay ST, Suzuki Y, Cho BC, Kuroda D, Arima K, Izumi D, Iwatsuki M, Baba Y, Oki E, Watanabe M, Saya H, Hirakawa K, Baba $\mathrm{H}$ and Tan P: Activation of transforming growth factor beta 1 signaling in gastric cancerassociated fibroblasts increases their motility, via expression of rhomboid 5 homolog 2 , and ability to induce invasiveness of gastric cancer cells. Gastroenterol 153(1): 11-204, 2017.

10 Matsuda G, Nakajima K, Kawaguchi Y, Yamanashi Y and Hirai $\mathrm{K}$ : Epstein-Barr virus (EBV) nuclear antigen protein (EBNA-LP) forms complexes with a cellular anti-apoptosis protein Bcl-2 or its EBV counterpart BHRF1 through HS1-associated protein X1. Microbiol Immunol 47(1): 91-99, 2003.

11 Polz-Dacewicz M, Strycharz-Dudziak M, Dworzański J, Stec A and Kocot J: Salivary and serum IL- 10 , TNF- $\alpha$, TGF- $\beta$, VEGF levels in oropharyngeal squamous cell carcinoma and correlation with HPV and EBV infection. Infect Agent Cancer 11: 45-53, 2016.

12 Foltyn S, Strycharz-Dudziak M, Drop B, Boguszewska A and Polz-Dacewicz M: Serum EBV antibodies and LMP-1 in Polish patients with oropharyngeal and laryngeal cancer. Infect Agent Cancer 12: 31, 2017.

13 Bae JM and Kim EH: Epstein-Barr virus and gastric cancer risk: A meta-analysis with meta-regression of case-control studies. J Prev Med Public Health 49(2): 97-107, 2016.

14 Chen CJ, Hsu WL, Yang HI, Lee MH, Chen HC, Chien YC and You SL: Epidemiology of virus infection and human cancer. Recent Results Cancer Res 193: 11-32, 2014.

15 Cho J, Kang MS and Kim KM: Epstein- Barr virus associated gastric carcinoma and specific features of the accompanying immune response. J Gastr Cancer 16(1): 1-7, 2016.

16 Kang MS and Kieff E: Epstein-Barr virus latent genes. Exp Mol Med 47: e131, 2015.

17 Murphy G, Pfeiffer R, Camargo MC and Rabkin CS: Metaanalysis show that prevalence of Epstein-Barr virus-positive gastric cancer differs based on sex and anatomic location. Gastroenterol 137(3): 824-833, 2009.

18 Shinozaki-Ushiku A, Kunita A and Fukayama M: Update on Epstein-Barr virus and gastric cancer. Int J Oncol 46(4): 14211434, 2015.

19 Tajima M, Takeda F, Takeshima T, Yokohata T and Okinaga K: Human herpesviruses infections (I) - EBV infection and immunity in cancer patients. Kansenshogaken Zasshi 65(7): 799807, 1991.

20 Kayamba V, Monze M, Asombang AW, Zyambo K and Kelly P: Serological response to Epstein-Barr virus early antigen is associated with gastric cancer and human immunodeficiency virus infection in Zambian adults: a case-control study. Pan Afr Med J 23: 45-52, 2016.

21 Schetter AJ, You WC, Lennette ET, Gail M and Rabkin CS: Association of Epstein-Barr virus antibody levels with precancerous gastric lesions in high-risk cohort. Cancer Sci 99(2): 350-354, 2008.

22 Sairenji T, Tajima M, Kanamori M, Takasaka N, Gao X, Murakami M, Okinaga K, Satoh Y, Hoshikawa Y, Ito H, Miyazawa Y and Kurata T: Characterization of EBV-infected epithelial cells lines from gastric cancer-bearing tissues. Curr Top Microbiol Immunol 258: 185-198, 2001.

23 Imai S, Koizumi S, Sugiura M, Tokunaga M, Uemura Y, Yamamoto N, Tanaka S, Sato E and Osato T: Gastric carcinoma: monoclonal epithelial malignant cells expressing Epstein-Barr virus latent infection protein. Proc Natl Acad Sci USA 91(19): 9131-9135, 1994.

24 Niedobitek G and Yung LS: Epstein-Barr virus persistence and virus-associated tumours. Lancet 343(8893): 333-335, 1994.

25 Reza MA, Reza MH, Mehdieyeh L, Mehdi F and Hamid ZN: Evolution frequency of Merkel cell polyoma, Epstein-Barr and mouse mammary tumor viruses in patients with Breast cancer in Kerman, southeast of Iran. Asian Pac J Cancer Prev 16(16): 7351-7357, 2015.

26 Ryan JL, James RJ, Kenney SC, Rivenbark AG, Tang W, Knight ER, Coleman WB and Gulley ML: Epstein-Barr virus - specific methylation of human genes in gastric cancer cells. Infect Agent Cancer 5: 27, 2010.

27 Wang A, Zhang W, Jin M, Zhang J, Li S, Tong F and Zhou Y: Differential expression of EBV proteins LMP-1 and BHFR1 in EBV-associated gastric and nasopharyngeal cancer tissues. Molecular Medicine Reports 13(5): 4151-4158, 2016.

28 Da Costa VG, Ariany C, Marques-Silva AC and Moreli ML: The Epstein-Barr virus latent membrane protein-1 (LMP-1) 30bp deletion and XhoI-polymorphism in nasopharyngeal carcinoma: a meta-analysis of observational studies. Syst Rev 4: 46, 2015.

29 Mori S, Itoh T, Tokunaga M and Eizuru Y: Deletions and singlebase mutations within the carboxy-terminal region of the latent membrane protein 1 oncogene in Epstein-Barr virus-related gastric cancers of Southern Japan. J Med Virol 57(2): 152-158, 1999.

30 Tsao SW, Tsang CM, To KF and Lo KW: The role of EpsteinBarr virus in epithelial malignancies. J Pathol 235(2): 323-333, 2015.

31 Choi CK, Ho DN, Hui KF, Kao RY and Chiang AKS: Identification of novel small organic compounds with diverse structures for the induction of Epstein-Barr Virus (EBV) lytic cycle in EBV-positive epithelial malignancies. PloS One 10(12): e0145994, 2015.

32 Shukla SK, Khatoon J, Prasad KN, Rai RP, Singh AK, Kumar $S$, Ghoshal U and Krishnani N: Transforming growth factor beta 1 (TGF $\beta$-1) modulates Epstein-Barr virus reactivation in absence of Helicobacter pylori infection in patients with gastric cancer. Cytokine 77: 176-179, 2016.

33 Ngan RK, Lan WH and Yip TT: Remarkable application of serum EBV EBER-1 in monitoring response of nasopharyngeal cancer patients to salvage chemotherapy. Ann NY Acad Sci 995: 73-79, 2001.

34 Rosa MD, Gottlieb E, Lerner MR and Steitz JA: Striking similarities are exhibited by two small Epstein-Barr virusencoded ribonucleic acids and the adenovirus associated ribonucleic acids VAI and VAII. Mol Cell Biol 1(9): 785-796, 1981.

35 Ruf IK, Rhyne PW, Yang C, Cleveland JL and Sample JT: Epstein-Barr virus small RNAs potentiate tumorigenicity of Burkitt Lymphoma cells independently of an effect on apoptosis. J Virol 74(21): 10223-10228, 2000.

36 Căinap SS, Fetică B, Buiga R, Căinap C, Constantin AM and Şovrea AS: The prognostic role of EBER in pediatric cancer. Rom J Morphol Embroyol 56(4): 1269-1277, 2015.

37 Lamberdt SL and Martinez OL: Latent membrane protein 1 of EBV activates phosphatidylinositol 3-kinase to induce production of IL-10. J Immunol 179(12): 8225-8234, 2007. 
38 Mosser DM and Zhang X: Interleukin-10: new perspectives on an old cytokine. Immunol Rev 226: 205-218, 2008.

$39 \mathrm{Ng} \mathrm{TH}$, Britton GJ, Hill EV, Verhagen J, Burton BR and Wraith DC: Regulation of adaptive immunity; the role of interleukin10. Front Immunol 4: 129, 2013.

40 Chao Y, Jing Y, Jia Y, Wang, Y, Zhao C and Luo B: Conservation and mutation of viral interleukin-10 gene in gastric carcinomas and nasopharyngeal carcinomas. J Med Virol 83(4): 644-650, 2011.

41 McKenzie J, Lopez-Giraldez F, Delecluse HJ, Walsh A and ElGuindy A: The Epstein-Barr virus immunoevasins BCRF1 and BPLF1 are expressed by a mechanism independent of the canonical late pre-initiation complex. PLOS Pathogens 12(11): e1006008, 2016.
42 De Vita F, Orditura M, Galizia G, Romano C, Infusino S, Auriemma A, Lieto E and Catalano G: Serum interleukin-10 levels in patients with advanced gastrointestinal malignancies. Cancer 86(10): 1936-1943, 1999.

43 Zhao J, Liang Q, Cheung KF, Kang W, Lung RW, Tong JH, To $\mathrm{KF}$, Sung JJ and Yu J: Genome-wide identification of EpsteinBarr virus-driven promoter methylation profiles of human genes in gastric cancer cells. Cancer 119(2): 304-309, 2013.

Received June 1, 2017

Revised July 3, 2017

Accepted July 6, 2017 